\title{
FACTORS ASSOCIATED WITH RISKY BEHAVIOR FOR HIV/AIDS TRANSMISSION AMONG YOUTH ORGANIZATION IN DEPOK, WEST JAVA
}

\author{
Nunuk Nugrohowati'), Ria Maria Theresa') \\ ${ }^{1)}$ Department of Public Health, Faculty of Medicine, UPN Veteran Jakarta \\ 2)Department of Mental Health Science, Faculty of Medicine, \\ UPN Veteran Jakarta
}

\begin{abstract}
Background: Depok Health Office, West Java, in 2017 reported that there were 278 HIV infection cases in 2016. In Indonesia, there are 785,821 HIV infection cases, including 90,915 new HIV infection cases. This study aimed to determine the factors associated with risky behavior of HIV/AIDS transmission among youth organizations in Depok city, West Java.

Subjects and Method: A cross-sectional study was conducted in Depok city, West Java. A total of 50 respondents was selected for this study at random. The dependent variable was HIV/AIDS risky behavior. The independent variables were knowledge, attitude, information source, parenting style, traumatic experience, and peer-group influence. The data were collected by questionnaire and analyzed by multiple logistic regression.

Results: HIV/AIDS risk behavior increased by lack of knowledge (OR $=0.19 ; 95 \%$ $\mathrm{CI}=0.43$ to $0.86 ; \mathrm{p}=0.006)$, poor parenting style $(\mathrm{OR}=0.15 ; 95 \% \mathrm{CI}=0.02$ to 0.96 ; $\mathrm{p}=0.016)$, traumatic experience $(\mathrm{OR}=12.21 ; 95 \% \mathrm{CI}=1.64$ to $91.04 ; \mathrm{p}=0.017)$, and poor peer-influence $(\mathrm{OR}=6.50 ; 95 \% \mathrm{CI}=1.71$ to $24.68 ; \mathrm{p}=0.007)$.

Conclusion: HIV/AIDS risky behavior increases by lack of knowledge, poor parenting style, traumatic experience, and poor peer-groupinfluence.

Keywords: HIV/AIDS risky behavior, knowledge, attitude, information sources, parenting style, traumatic experience, peer-group influence

\section{Correspondence:}

Nunuk Nugrohowati. Department of Public Health, Faculty of Medicine, UPN Veteran Jakarta. Jl. Raya Fatmawati No 1, South Jakarta, Indonesia. Email: nnugrohowati@gmail.com. Mobile: +6287875556031 .
\end{abstract}

